\title{
23
}

\section{Sustainable Financing for Municipal Stormwater Management Programs}

\section{Mike Gregory, Ray Tufgar and Steve Sedgwick}

Municipal stormwater management (SWM) programs represent significant public investments that are largely funded through property taxes in Canada. Stormwater revenue drawn from taxes must compete with many other municipal services, and is often inadequate to provide an acceptable level of service demanded by the community. In addition to meeting current needs, municipalities must also finance future program revenue requirements (e.g. to renew or replace aging infrastructure, to comply with new stormwater regulations, or to operate and maintain additional facilities due to new development). Competing demands for limited tax funds will force municipalities to pursue alternative financing mechanisms in order to provide a financially sustainable SWM program.

In this chapter, a stormwater rate is investigated as an alternative sustainable financing mechanism. A stormwater rate that is based on each property's contribution to runoff quantity and quality offers a logical and legally defensible method for allocating municipal SWM program costs. Revenue is thus generated as a user fee, and in a more fair and equitable manner than the assessed property value. Stormwater rates are a relatively new concept in Canada, but have been successfully implemented in hundreds of municipalities throughout the United States.

Recent case studies in Ontario are used to highlight the issues and approaches for developing a stormwater rate as a sustainable financing option. All monetary amounts in this chapter are given in Canadian dollars.

Gregory, M., R. Tufgar and S. Sedgwick. 2010. "Sustainable Financing for Municipal Stormwater Management Programs." Journal of Water Management Modeling R236-23. doi: 10.14796/JWMM.R236-23. (C) CHI 2010 www.chijournal.org ISSN: 2292-6062 (Formerly in Dynamic Modeling of Urban Water Systems. ISBN: 978-0-9808853-3-0) 


\subsection{Background}

Stormwater management systems represent valuable public assets that provide a number of benefits for many users. Municipalities are generally responsible for managing all aspects of stormwater within their jurisdiction, including operations and maintenance (O\&M) of SWM facilities located within the public right-of-way limits or easements. The municipal SWM system may include watercourses, culverts, bridges, storm sewers, swales, catchbasins, inlets, outfalls, ponds and other water quality treatment devices.

By controlling floodwaters and preventing pollutants from reaching streams, rivers and lakes, SWM systems can protect the health and safety of the public and the environment as well as minimize flooding and erosion threats to public and private property. In so doing, clean and healthy water resources support public drinking water supplies, and can attract local investment through increased land values. Furthermore, clean water resources can support recreational activities, tourism, business and manufacturing, as well as healthy aquatic and terrestrial habitats.

Despite substantial investments in municipal SWM systems and facilities, there will always be a need to invest in new capital improvement projects and to reinvest in the operation, maintenance, planning, and management of the SWM program. Like other public works, SWM facilities and related infrastructure must be inventoried, assessed, valued, and managed according to sound asset management principals in order to plan an appropriate schedule for replacement, renewal, and rehabilitation.

Of all the public works provided by a municipality, SWM services are often the least understood by members of the community. Storm pipes are underground and out of sight, detention facilities and ponds are presumed to be natural features and the function of SWM facilities and practices are not easily perceived. As a result, there is little public awareness of a municipality's SWM program needs and costs.

Stormwater management systems often only attract attention during periods of rainfall, particularly if systems fail or rainfall exceeds the design capacity and property damage or road flooding result. As well, property owners have widely varying perceptions concerning how their properties generate stormwater runoff, since usage of the municipal SWM system is not based on demand, like water and sewage systems (e.g. turning on a tap or flushing a toilet). This may result in the misconception that property owners cannot control their stormwater discharge into the municipal SWM system.

Unlike other public works, particularly in comparison to wastewater and po- 
table water systems, SWM regulations and design standards are relatively new and evolving, resulting in many existing SWM systems and facilities that do not meet current federal or provincial requirements for the construction of new facilities or long term maintenance. More stringent federal and provincial requirements for water quality and quantity control are also being proposed, further widening the gap to bring these publicly-owned systems into compliance.

Although municipal governments are responsible for managing all aspects of stormwater within their jurisdiction, they have limited flexibility and autonomy in generating revenue. In cases where the resource requirements placed upon a community far exceed the available resources appropriated by the elected officials, the implementation of capital projects, or the extent and frequency of O\&M activities, for example, become dependent on the availability of funds, rather than based on need.

\subsection{Stormwater Funding Options}

To support current and future needs, the general mechanisms for funding the major components of a municipal SWM program may include the following:

- Taxes, which are mandatory levies authorized by the legislature, collected by a public body, and not related to any specific benefit or government service (i.e. these are for general services to support the public good);

- Fees and special charges, which are payments made to offset the cost of a specific service and payable by those people who benefit from the service;

- Special levies that have specific designations and limitations for usage;

- Other means besides taxes, fees, and special levies, such as public-private partnerships, long term debt-financing strategies, federal or provincial economic stimulus grants for infrastructure investment; and

- A combination of the above.

Based on recent municipal SWM financing studies in Ontario (Totten Sims Hubicki Associates [now AECOM] and Camp Dresser \& McKee, 2007; 2008a; $2008 \mathrm{~b}$ ), the funding options that are most applicable to municipalities for covering a wide range of SWM expenditures are:

- Property taxes: These are the primary source of funding for SWM programs throughout Canada; 
- Development related charges and fees: These are common funding sources for municipal SWM programs throughout Canada and the United States; and

- Stormwater rate: At least three municipalities in Ontario (London, St. Thomas and Aurora) have implemented a special stormwater user fee that charges a flat rate to residential properties, and an area-based charge to commercial/industrial properties. Other municipalities in Ontario are known to be evaluating various stormwater funding options. There are approximately a dozen municipalities in western Canada that have either adopted a stormwater rate, either as a flat rate user fee (Regina and Saskatoon, Saskatchewan; Calgary, St. Albert and Strathcona County, Alberta) or a rate based on zoning and intensity of development (Edmonton, Alberta; Langley and Richmond, British Columbia). Nearly 650 stormwater rates have been implemented in communities throughout the United States.

These options are described in detail in the following subsections.

\subsubsection{Property Tax}

Revenue derived from the municipality's portion of property tax goes into a general fund to cover the operating and capital expenditures of many services across several departments, including SWM. The amount of tax levied on a particular property is based upon the property value assessment. The assessment amount is multiplied by an applicable tax rate, which in turn depends on zoning, building type, and taxing status. Municipalities may also collect tax revenue on behalf of school boards and the regional government.

Tax-exempt properties generally do not contribute to the municipality's SWM program. Tax-exempt properties include governmental parcels (e.g. municipal, regional, provincial and federal buildings) as well as institutional parcels such as schools, hospitals or churches, and other charitable organizations that are registered with the Canada Revenue Agency and therefore exempt from taxation under the Income Tax Act.

A dedicated levy can be administered specifically to raise revenue for stormwater services, such that a fixed property tax rate is applied and itemized on the property owner's annual tax bill, as is done for other public services including police, fire, transit, and local improvements. A by-law would be required to dedicate these funds specifically to SWM. With the general tax fund, money to support the SWM program comes from the municipality's over- 
all tax rate and is not dedicated until the annual budget is set each year.

The primary advantage of using property taxes to support the municipal SWM program, either through a general tax fund or dedicated levy, is that this method is already accepted as the primary existing source of revenue for municipalities and the billing system is already established. The primary disadvantages are that the fairness and equity in allocating charges is low; it is not a sustainable revenue stream; there are no incentive opportunities to reduce stormwater runoff and pollutant discharge; and many large properties do not contribute to the funding (tax-exempt properties).

\subsubsection{Development Related Charges and Fees}

In Ontario, the Development Charges Act of 1997 authorizes municipalities to pass by-laws for the recovery of costs incurred to provide services to new and re-development projects. Development charges (DC) can only be utilized to fund eligible growth-related capital costs, and only for the services for which they were collected. Rates for DC are often based on the number of residential dwelling units or the building floor area for non-residential developments. Area-specific DC rates can be charged depending on location. Revenue derived from DC can be applied to projects throughout the municipality.

In areas where there is the potential for re-development or infill, and on-site SWM facilities are considered infeasible (e.g. by presenting an undue maintenance burden on the municipality), contributions to off-site SWM facilities can be allocated in the form of a cash-in-lieu policy. Like DC, cash-in-lieu rates are based on the area of development (or number of dwelling units) and areaspecific rates can be determined for different geographic locations within the community. Unlike DC, however, revenue derived from cash-in-lieu charges can be applied to both capital and O\&M costs of SWM facilities.

Another form of development related charges used in Ontario to fund the municipality's SWM program is those made through the use of subdivision agreements. These are one-time agreements for area-specific capital works in new development subdivisions. Cost sharing for joint facilities can also be accommodated. The present value costs of anticipated future O\&M and ongoing monitoring can also be included in the agreement.

The primary advantage of these development related charges is that they are currently accepted by the development community. The primary disadvantages are that these methods are limited by the amount of developable land within municipality and are directly dependent on growth and economic conditions. 


\subsubsection{Stormwater Rate}

A stormwater rate involves assessing a charge to all property owners for the municipality's SWM services based on the amount of impervious area. The rate is based on the contribution of stormwater runoff from each property to the local drainage system and water quality control facilities. Revenue generated through the rate can be used for any SWM program related costs.

A stormwater rate is a more equitable funding mechanism than other funding sources, because fees assessed to each parcel of land are based on usage of the drainage system rather than property value. Because commercial and industrial properties generally generate much more runoff and stormwater pollution per square meter or square foot than single family residential properties, these properties are charged a proportionally greater fee.

All parcels, including tax-exempt properties, can be assessed a charge that reflects their relative stormwater contribution to the municipal SWM system. For example, each tax-exempt parcel could be charged a stormwater user fee that is proportional to the stormwater discharge from the property. This method is similar to other public utilities that bill tax-exempt properties based on usage, such as electricity/hydro or water providers.

The area of impervious ground cover is typically used as the basis for the stormwater rate, because imperviousness is a common indicator of both stormwater runoff volume and pollution loading potential from a given tributary area. Imperviousness is an indirect measure of urbanization with values ranging from $0 \%$ (e.g. natural areas with well-drained permeable soils) to $100 \%$ (e.g. urban areas completely covered in impervious materials). Impervious surfaces may include paved roadways, parking areas, driveways, sidewalks, building rooftops and similar structures. Heavily compacted soils, gravel areas, and waterbodies can also have impervious characteristics.

Urban development can result in a combination of adverse impacts in developing watersheds. In addition to increased imperviousness, construction activities associated with development involve clearing of vegetation and surface soil layers to be replaced with graded and compacted fill and topsoil. In addition, natural drainage patterns are altered and replaced with engineered systems and facilities. The resulting impacts are often cumulative, affecting fish and wildlife in various ways, and therefore pose potentially significant monetary and ecological costs to citizens and local governments within a watershed (Schueler, 2003; U.S. Environmental Protection Agency, 1997).

Imperviousness is a useful designation for many objectives, including regulatory compliance, watershed modeling and analysis, and cost allocation as the basis for a stormwater rate (Camp Dresser \& McKee, 2007; Gregory et. al., 
2006). A variety of methods can be used to estimate imperviousness, including GIS tools and mapping tools (Stocker, 1998; Lee and Heaney, 2003). Since stormwater rates are generally applied across a municipality or group of municipalities, it is cost-effective to interpret land cover characteristics from digital aerial photographs, with field verification as necessary.

The average impervious area per dwelling unit for residential land use categories is typically designated as the base unit for a stormwater rate. The base unit represents the stormwater discharge potential of the average residential dwelling and its associated lot. It can be based on all residential development (including multi-family) or on single family detached homes only. The average impervious area of the base unit is calculated by summing the impervious area for all residential parcels and dividing by the total number of dwelling units.

A stormwater rate typically charges a flat fee to each residential dwelling unit, and to a non-residential parcel a fee based on the ratio of the parcel's impervious area to that of the base unit. For example, if a commercial or industrial parcel has four times the impervious area of the base unit, the parcel would be billed four times the flat fee for residential dwelling units. A stormwater rate charge is commonly applied on a monthly or quarterly basis.

Funding through a stormwater rate has the primary advantages of being a fair and equitable allocation of charges to property owners, being a financially sustainable and dedicated funding source, providing incentive opportunities to reduce stormwater runoff and pollutant discharge, and providing a mechanism to charge tax-exempt properties for municipal SWM services. The primary disadvantages include additional costs for rate implementation and the possibility that a new fee may not be well received by the public. A new fee structure might also be reluctantly received by municipal staff if it does not fit well within the current financial and policy framework dominated by property tax revenue.

\subsubsection{Considerations for Selecting Funding Options}

As noted in the Ontario financing studies (Totten Sims Hubicki Associates [now AECOM] and Camp Dresser \& McKee, 2007; 2008a; 2008b), an ideal municipal SWM funding source would have the following characteristics:

- Costs are allocated in a fair and equitable manner;

- It provides a sustainable and dedicated funding source to support SWM program needs;

- It is applicable for use on a municipality-wide basis;

- Expected revenue meets the requirements for the optimum level 
of service provided and appropriate reserve funding levels are maintained;

- Its costs and benefits are equitably distributed, and are transparent and visible across the community;

- Specifically for the case of fees and special charges, sound policies are in place for credits, adjustments and appeals, and rate study recommendations are publicly supported;

- It has reasonable implementation costs (e.g. charges, managing billing systems and overall administration); and

- It is consistent with provincial and federal legislation.

Only the property tax and the stormwater rate alternatives address all aspects of a comprehensive SWM program on a municipality-wide scale. Development related charges and other funding mechanisms are an important source of revenue, but cannot be used solely to support the entire program. In many cases, a combination of funding sources is deemed to be the most appropriate to meet the revenue requirements for a municipal SWM program (e.g. DC to support growth-related expenditures and blended tax or rate revenue to support non-growth capital and O\&M expenditures).

The remainder of this chapter presents a discussion of the application of a stormwater rate for Canadian municipalities.

\subsection{Stormwater Rate Analysis Results}

In this section, results from stormwater rate analyses are summarized for three municipalities in Ontario, including the cities of Kitchener, Stratford, and Waterloo. Table 23.1 summarizes the basic demographic and land area information for these municipalities. The table includes the upper tier municipality along with the latest census population from 2006, total land area, growth rate (change in population since the previous census in 2001), and the population density in people $/ \mathrm{km}^{2}$.

Table 23.1 Summary of Ontario municipalities undertaking stormwater rate studies.

\begin{tabular}{llcccc}
\hline Municipality & $\begin{array}{c}\text { Upper Tier Munici- } \\
\text { pality }\end{array}$ & $\begin{array}{c}\text { Population } \\
(2006 \text { Cen- } \\
\text { sus })\end{array}$ & $\begin{array}{c}\text { Population } \\
\text { Change, } \\
2001-2006\end{array}$ & $\begin{array}{c}\text { Total Land } \\
\text { Area }\left(\mathrm{km}^{2}\right)\end{array}$ & $\begin{array}{c}\text { Population } \\
\text { Density (per } \\
\left.\mathrm{km}^{2}\right)\end{array}$ \\
\hline Kitchener & Waterloo Region & 204668 & $7 \%$ & 137 & 1495 \\
Stratford & n.a. (single tier) & 30461 & $2 \%$ & 25 & 1205 \\
Waterloo & Waterloo Region & 97475 & $13 \%$ & 64 & 1521 \\
\hline
\end{tabular}




\subsubsection{Stormwater Rate Base Charge Calculations}

The basic calculation for a stormwater rate is simply the municipal SWM program expense divided by the number of billing units within the municipality. Program costs, particularly capital expenditures, can fluctuate widely on an annual basis. As a result, the program expense term in the rate calculation numerator is usually taken as the average annual SWM expenditure over a suitable planning period (e.g. $5 \mathrm{y}$ to $10 \mathrm{y}$ ).

To determine the billing unit denominator, there are a number of methods to allocate a stormwater charge to property owners that have been used in stormwater rate implementations throughout North America. These methods, in terms of fairness and equity of charge allocation, are, in increasing order of accuracy:

- Flat Rate: The charge does not vary according to usage of the property (e.g. \$7/month per water meter account, or $\$ 1000 /$ ha/month for industrially zoned properties);

- Runoff Coefficient: The charge varies by property size and an assumed coefficient that reflects stormwater runoff potential by property type (e.g. residentially zoned properties are assigned a runoff coefficient of 0.4 and industrially zoned properties are assigned a runoff coefficient of 0.7 );

- Intensity of Development Factor: This method is similar to the runoff coefficient billing method; however, adjustment factors are applied to account for the property's development status (a factor of 0.0 for undeveloped properties, 1.0 for fully developed properties, and a factor between 0.0 and 1.0 for properties considered to be underdeveloped within their underlying zoning category);

- Equivalent Residential Unit (ERU): A statistical sampling of measured impervious areas for residential dwelling units is performed to determine the average ERU size $\left(\mathrm{m}^{2}\right.$ of impervious area). The average impervious area for all types of residential dwelling units becomes the base billing unit. Charges for residential properties are based on assigning one stormwater billing unit to each residential dwelling unit. Given the wide variability in impervious area statistics for non-residential properties, the impervious area for each non-residential property must be measured. The charge for non-residential properties is determined by dividing the measured impervious area by the average ERU size; 
- Single Family Unit (SFU): A statistical sampling of measured impervious area for single-family detached homes is performed to determine the average SFU size (i.e. $\mathrm{m}^{2}$ of impervious area). The average impervious area for single-family detached homes becomes the base billing unit with one stormwater billing unit assigned to each single-family detached home and fractional billing units assigned to other residential property types. Multifamily residential properties such as apartments, condominiums and townhouses have a smaller SFU size than single-family detached homes. The charge for non-residential properties is determined by dividing the measured impervious area by the average SFU size;

- Tiered Residential Rate (Tiered SFU): The tiered SFU billing unit method extends the SFU method by accounting for the variability in impervious area among single-family detached homes, such that three residential tiers are identified:

- Single Family (Small): Based on the impervious area of properties below the 11th percentile of single family homes;

- Single Family (Medium): Based on the impervious area of properties within the 11 th to 90 th percentiles of single family homes; and

- Single Family (Large): Based on the impervious area of properties above the largest 90th percentile of single family homes;

- Level-of-Service/Geography Base: The ERU and SFU billing unit methods can be extended to include separate rate structure calculations that vary by the level of service provided within distinct geographical boundaries (e.g. a higher rate in urban areas that receive more frequent O\&M activities and facilities that provide a higher level of flood protection than in rural areas); and

- Impervious Area Measurement (Complete Coverage): The most accurate of all billing unit methods is to measure the impervious area of all properties within a given jurisdiction.

The stormwater rate studies in Ontario focused on the ERU, SFU and tiered SFU billing unit methods, as these were felt to provide the best balance between accuracy (in terms of fairness and equity) and level of effort (in terms of rate administration costs). 


\subsubsection{Expenditure Analysis}

Table 23.2 shows the average annual SWM program expenditures for the three Ontario communities. All dollar amounts have been rounded to the nearest thousand. For comparison purposes, annual SWM program expenditures were taken for a common period (fiscal year 2007) and in each case were based on a financial analysis of projected SWM program costs that was undertaken in 2006. Actual 2007 expenditures may differ from the numbers shown in the table. Further, the expenditures shown in Table 23.2 represent non-growth related expenditures. All three cities have development charges programs in place; however, activities funded through each city's respective DC program have not been included in the table and were not considered for inclusion in the proposed stormwater rate analysis.

Table 23.2 Average annual SWM program expenditures (fiscal year 2007, projected).

\begin{tabular}{lrrrr}
\hline \multicolumn{1}{c}{ Municipality } & $\begin{array}{l}\text { Operations \& } \\
\text { Maintenance }\end{array}$ & \multicolumn{1}{c}{ Capital } & \multicolumn{1}{c}{ Other } & $\begin{array}{c}\text { Total Program } \\
\text { Cost }\end{array}$ \\
\hline Kitchener & $\$ 1591000$ & $\$ 4085000$ & $\$ 145000$ & $\$ 5821000$ \\
Stratford & $\$ 525000$ & $\$ 6853000$ & $\$ 235000$ & $\$ 7613000$ \\
Waterloo & $\$ 1546000$ & $\$ 989000$ & $\$ 527000$ & $\$ 3062000$ \\
\hline
\end{tabular}

The cost components shown in Table 23.2 have been grouped into the following categories:

- Operations and Maintenance (O\&M): This category includes vital tasks such as inspection, cleaning, repair, and replacement of the various stormwater system components. Precautionary maintenance performed on a regular basis throughout the system includes such activities as street sweeping, leaf collection, catch basin maintenance, spill prevention, and ditch cleaning. Nonroutine services performed as needed may include removal of silt, sediment, debris, and vegetation. Other SWM program items that may be included under O\&M include response to customer complaints, emergency repair and replacement, and emergency spill response;

- Capital Improvement Projects: These include reconstruction projects that involve work on existing infrastructure and special projects including system rehabilitation, renewal, and retrofit projects. Additional capital expenditures could include activities 
associated with administering the capital program, such as support and overhead items, program development, infrastructure mapping, asset management planning, project management, procurement, and contract administration associated with the stormwater system; and

- Other SWM Program Activities: This category includes stormwater related expenditures that are not directly related to the O\&M and capital programs. This may include activities related to environmental compliance, intergovernmental payments, or contributions to reserve funds.

Table 23.2 above indicates the distribution of SWM program costs by component varies widely. For example, the SWM programs in Kitchener and Stratford are dominated by capital projects $(70 \%$ and $90 \%$ of their respective total program costs) compared to Waterloo (32\%). Also, Waterloo's SWM program has a higher proportion of O\&M costs (50\%) compared to Kitchener and Stratford ( $27 \%$ and $7 \%$ respectively).

While there is a general correlation between stormwater O\&M costs and the total amount of impervious area within a municipality, there is wide variability among capital costs in municipal SWM programs. As an example, the City of Stratford is facing major capital requirements for the construction of SWM storage and conveyance facilities to protect homes and businesses from property damage. This is evident by expressing the costs shown in Table 23.2 above on a per capita basis, that is, Stratford's SWM program is equivalent to $\$ 250$ per capita whereas the Kitchener and Waterloo SWM programs are approximately $\$ 30$ per capita. Long term financing options for capital projects can greatly reduce the annual revenue requirements. Long term financing scenarios were investigated during the course of the Stratford study; however, these have not been included in this chapter.

\subsubsection{Billing Unit Analysis}

Deriving an appropriate base charge involves coupling the municipality's specific SWM program revenue requirements with a billing unit analysis (McClelland et al., 2003). The billing unit analysis identifies and characterizes the impervious characteristics of parcels with respect to their runoff contribution, and therefore, relative use of the municipal SWM system and services. A parcel refers to any contiguous property, lot or land tract under single ownership. The total number of the various types of parcels located within a municipality affects how much revenue a stormwater rate can generate. 
Several factors influence the characteristics of stormwater generated by a particular parcel of land. Parcel size, soil type, topography, impervious area, and development intensity interact to influence the volume of stormwater runoff and pollutant loading from a parcel. An analysis of extreme rainfall events used in stormwater planning and design has shown that the amount of impervious area is the most important parameter affecting the quantity and quality of runoff. Because this value is easily quantified, stormwater rate policies typically focus on impervious area for allocating SWM costs to customers.

The development of stormwater billing units, and the corresponding rate structures and policies, requires information regarding parcels within a program service area. For the Ontario studies, a database of parcels was created and used to establish the parcel distribution and estimated impervious areas by parcel type. The parcel database was developed based on the following data sources:

- Aerial photography and parcel boundary data in GIS format;

- Tax assessment data from the Municipal Property Assessment Corporation describing the number of parcels and land use categories;

- Parcel boundaries from hard copy maps to affirm total land areas within each jurisdiction;

- Utility billing data to account for the number of customers by utility classifications in each community; and

- Any existing information to help correlate data between the parcel and utility databases for customer classifications.

Once the parcel database was created, a statistical sampling of the residential land use categories was performed. The objective of the sampling process was to estimate the average impervious area per dwelling unit in each residential category with a $95 \%$ confidence interval that is within $10 \%$ of the average impervious area. Between 400 and 500 samples were used in each city to derive the single-family detached impervious area statistics. Representative samples were taken over a range of geographical areas, property sizes, and property values. This statistical sampling process provides an accurate, defensible estimate for residential impervious area determinations, which form the basis for the stormwater rate structure described below.

Multi-family residential parcels include any development with two or more residential units in the development. Impervious area statistics for multiresidential parcels were derived from a sample size representing $>1000$ dwelling units in each city. The number of dwelling units had to be field-verified as the assessment database did not include this information. For a limited number of parcels which involved duplex, triplex, and quadplex buildings, no additional field verification was required to obtain the number of dwelling units. 
While the imperviousness of residential properties generally falls within an expected statistical distribution, the range for non-residential properties is highly variable. That is, a sampling of non-residential properties cannot achieve the same statistical confidence as with residential properties. For the Kitchener and Waterloo studies, it was not within the project scope to measure all nonresidential properties. As a result, impervious areas were estimated based on experience in similar communities.

Tables 23.3, 23.4 and 23.5 show the results of the billing unit analysis using the tiered SFU method for the cities of Kitchener, Stratford and Waterloo, respectively.

Table 23.3 City of Kitchener billing unit analysis (tiered SFU).

\begin{tabular}{|c|c|c|c|c|c|c|c|}
\hline \multirow{2}{*}{ Parcel Type } & \multirow{2}{*}{$\begin{array}{c}\text { Number } \\
\text { of } \\
\text { Parcels }\end{array}$} & \multirow{2}{*}{$\begin{array}{c}\text { Dwelling } \\
\text { Units } \\
\text { (d.u.) }\end{array}$} & \multicolumn{2}{|c|}{$\begin{array}{c}\text { Est'd } \\
\text { Impervious Area }\left(\mathrm{m}^{2}\right)\end{array}$} & \multirow{2}{*}{$\begin{array}{l}\text { SFU } \\
\text { Factor }\end{array}$} & \multicolumn{2}{|c|}{$\begin{array}{l}\text { Tiered SFU } \\
\text { Distribution }\end{array}$} \\
\hline & & & Total & $\begin{array}{l}\text { Avg } \\
\text { /d.u. }\end{array}$ & & Count & $\%$ \\
\hline Single Family (small) & 4181 & 4181 & 702374 & 168 & 0.6 & 2508 & 3.1 \\
\hline Single Family (medium) & 33446 & 33446 & 8662618 & 259 & 1.0 & 33446 & 41.2 \\
\hline Single Family (large) & 4181 & 4181 & 1438195 & 344 & 1.3 & 5435 & 6.7 \\
\hline $\begin{array}{l}\text { Multi-Family (all catego- } \\
\text { ries) }\end{array}$ & 10681 & 37786 & 3358270 & 89 & $\begin{array}{r}0.2- \\
0.7 \\
\end{array}$ & 11616 & 14.3 \\
\hline Residential Subtotal & 52489 & 79594 & 14161458 & 178 & & 53005 & 65.2 \\
\hline Non-Residential & 2769 & n.a. & 5359285 & n.a. & n.a. & 20692 & 25.5 \\
\hline Non-Res'l (Tax Exempt) & 923 & n.a. & 1952074 & n.a. & n.a. & 7537 & 9.3 \\
\hline Total & 56181 & & 21472817 & & & 81234 & 100.0 \\
\hline
\end{tabular}

Table 23.4 City of Stratford billing unit analysis (tiered SFU).

\begin{tabular}{|c|c|c|c|c|c|c|c|}
\hline \multirow{2}{*}{ Parcel Type } & \multirow{2}{*}{$\begin{array}{c}\text { Number } \\
\text { of } \\
\text { Parcels }\end{array}$} & \multirow{2}{*}{$\begin{array}{c}\text { Dwelling } \\
\text { Units } \\
\text { (d.u.) }\end{array}$} & \multicolumn{2}{|c|}{$\begin{array}{c}\text { Est'd } \\
\text { Impervious Area }\left(\mathrm{m}^{2}\right) \\
\end{array}$} & \multirow{2}{*}{$\begin{array}{l}\text { SFU } \\
\text { Factor }\end{array}$} & \multicolumn{2}{|c|}{$\begin{array}{l}\text { Tiered SFU } \\
\text { Distribution }\end{array}$} \\
\hline & & & Total & $\begin{array}{l}\text { Avg } \\
\text { /d.u. }\end{array}$ & & Count & $\%$ \\
\hline Single Family (small) & 687 & 687 & 124484 & 181 & 0.6 & 412 & 2.2 \\
\hline Single Family (medium) & 5505 & 5505 & 1554931 & 282 & 1.0 & 5505 & 29.5 \\
\hline Single Family (large) & 687 & 687 & 274388 & 399 & 1.4 & 962 & 5.2 \\
\hline $\begin{array}{l}\text { Multi-Family (all catego- } \\
\text { ries) }\end{array}$ & 2325 & 5403 & 467105 & 86 & $\begin{array}{r}0.3- \\
0.5 \\
\end{array}$ & 1867 & 10.0 \\
\hline Residential Subtotal & 9204 & 12282 & 2420909 & 197 & & 8746 & 46.9 \\
\hline Non-Residential & 676 & n.a. & 2279649 & n.a. & n.a. & 8071 & 43.3 \\
\hline Non-Res'l (Tax Exempt) & 244 & n.a. & 519469 & n.a. & n.a. & 1839 & 9.9 \\
\hline Total & 10124 & & 5220027 & & & 18656 & 100.0 \\
\hline
\end{tabular}


Table 23.5 City of Waterloo billing unit analysis (tiered SFU).

\begin{tabular}{|c|c|c|c|c|c|c|c|}
\hline \multirow[t]{2}{*}{ Parcel Type } & \multirow{2}{*}{$\begin{array}{l}\text { Number } \\
\text { of } \\
\text { Parcels }\end{array}$} & \multirow{2}{*}{$\begin{array}{l}\text { Dwelling } \\
\text { Units } \\
\text { (d.u.) }\end{array}$} & \multicolumn{2}{|c|}{$\begin{array}{c}\text { Est'd } \\
\text { Impervious Area } \\
\left(\mathrm{m}^{2}\right)\end{array}$} & \multirow[t]{2}{*}{$\begin{array}{l}\text { SFU } \\
\text { Factor }\end{array}$} & \multicolumn{2}{|c|}{$\begin{array}{l}\text { Tiered SFU Distri- } \\
\text { bution }\end{array}$} \\
\hline & & & Total & $\begin{array}{l}\text { Avg } \\
\text { /d.u. }\end{array}$ & & Count & $\%$ \\
\hline Single Family (small) & 2002 & 2002 & 328377 & 164 & 0.6 & 1201 & $2.9 \%$ \\
\hline Single Family (medium) & 16018 & 16018 & 4260894 & 266 & 1.0 & 16018 & $38.8 \%$ \\
\hline Single Family (large) & 2002 & 2002 & 706812 & 353 & 1.3 & 2603 & $6.3 \%$ \\
\hline $\begin{array}{l}\text { Multi-Family (all cate- } \\
\text { gories) }\end{array}$ & 9558 & 22635 & 1814509 & 80 & $\begin{array}{r}0.2- \\
0.5\end{array}$ & 5952 & $14.4 \%$ \\
\hline Residential Subtotal & 29581 & 42658 & 7110592 & 167 & & 25774 & $62.4 \%$ \\
\hline Non-Residential & 1671 & n.a. & 3112274 & n.a. & n.a. & 11700 & $28.3 \%$ \\
\hline Non-Res'l (Tax Exempt) & 557 & n.a. & 1022287 & n.a. & n.a. & 3843 & $9.3 \%$ \\
\hline Total & 31809 & & 11245153 & & & 41317 & $100.0 \%$ \\
\hline
\end{tabular}

For each parcel type, these tables show the parcel distribution, number of residential dwelling units, and the estimated impervious area expressed in total square meters and as an average area per dwelling unit. Residential parcel types are categorized by the three single-family tiers noted earlier, and all multifamily residential properties are combined for comparison purposes. Nonresidential parcel types (such as commercial, industrial, institutional, and agricultural) are similarly lumped together. Properties that are currently tax-exempt have been itemized separately. It should be noted that the public road right-ofway is considered to be part of the municipal SWM system and is not included in a stormwater rate charge.

The SFU Factor column relates the average impervious area of each residential parcel type to the average single family detached home base area (the average impervious area for the Single Family (medium) entry in Tables 23.3, 23.4 and 23.5 above). A range of SFU factors is shown for multi-family residential properties. The final two columns in these tables show the distribution of tiered SFU billing units. For residential properties, the SFUs are assigned by multiplying the number of dwelling units by the SFU factor. For non-residential properties, the number of SFU billing units is determined by dividing the impervious area by the SFU base area.

As indicated by Tables 23.3, 23.4 and 23.5 above, the average impervious area of all residential properties, expressed per dwelling unit (the ERU base area), is:

- Kitchener: $178 \mathrm{~m}^{2}\left(1920 \mathrm{ft}^{2}\right)$;

- Stratford: $197 \mathrm{~m}^{2}\left(2120 \mathrm{ft}^{2}\right)$; and

- Waterloo: $167 \mathrm{~m}^{2}\left(1790 \mathrm{ft}^{2}\right)$. 
The Florida Stormwater Association published results of a stormwater rate survey of 115 Florida municipalities (counties and cities) in November 2007 (Florida Stormwater Association, 2007). An analysis of these results indicated the typical range of ERU base areas to be $>150 \mathrm{~m}^{2}$ and $<320 \mathrm{~m}^{2}\left(>1600 \mathrm{ft}^{2}\right.$ and $\left.<3400 \mathrm{ft}^{2}\right)$, with a typical average of $230 \mathrm{~m}^{2}\left(2500 \mathrm{ft}^{2}\right)$. The values noted above for the Ontario studies fall within this range.

The tables also indicate the average impervious area of single family detached homes (i.e., the SFU base area) is:

- $\quad$ Kitchener: $259 \mathrm{~m}^{2}\left(2790 \mathrm{ft}^{2}\right)$;

- Stratford: $282 \mathrm{~m}^{2}\left(3040 \mathrm{ft}^{2}\right)$; and

- Waterloo: $266 \mathrm{~m}^{2}\left(2860 \mathrm{ft}^{2}\right)$.

The total number and distribution of tiered SFU billing units in each city is:

- $\quad$ Kitchener: 81234 (65.2\% residential, 34.8\% non-residential);

- $\quad$ Stratford: 18656 (46.9\% residential, 53.1\% non-residential); and

- Waterloo: 41317 (62.4\% residential, 37.6\% non-residential).

\subsubsection{Stormwater Rate Results Evaluation}

In this section the stormwater rate calculations for the three Ontario municipalities are evaluated in two ways: the base charges needed to support the city's revenue requirements are compared against each other and in relation to other municipalities in North America, and the relative impacts on the overall SWM program revenue distribution (in comparison to current tax funding by property type category) are assessed.

\section{Base Charge}

As noted earlier, the base charge for a stormwater rate is determined by dividing the total SWM program expense by the total number of stormwater billing units. Table 23.6 summarizes the stormwater rate base charge calculations.

Table 23.6 Summary of base charge calculations.

\begin{tabular}{|c|c|c|c|c|c|c|c|c|c|c|c|}
\hline & \multicolumn{2}{|c|}{$\begin{array}{c}\text { Annual } \\
\text { Expenditures }\end{array}$} & \multicolumn{3}{|c|}{ ERU } & \multicolumn{3}{|c|}{ SFU } & \multicolumn{3}{|c|}{ Tiered SFU } \\
\hline $\begin{array}{l}\text { Munici- } \\
\text { pality }\end{array}$ & $\begin{array}{c}\text { Existing } \\
\text { SWM } \\
\text { Program } \\
\$ 1000\end{array}$ & $\begin{array}{l}\text { Rate } \\
\text { Admin- } \\
\text { istration }\end{array}$ & $\begin{array}{l}\text { Size } \\
\left(\mathrm{m}^{2}\right)\end{array}$ & $\begin{array}{l}\text { Billing } \\
\text { Units }\end{array}$ & $\begin{array}{c}\text { Charge } \\
\text { (\$/ERU/ } \\
\text { mo) }\end{array}$ & $\begin{array}{l}\text { Size } \\
\left(\mathrm{m}^{2}\right)\end{array}$ & $\begin{array}{c}\text { Billing } \\
\text { Units }\end{array}$ & $\begin{array}{c}\text { Charge } \\
(\$ / S F U / \\
\text { mo) }\end{array}$ & $\begin{array}{l}\text { Size } \\
\left(\mathrm{m}^{2}\right)\end{array}$ & $\begin{array}{l}\text { Billing } \\
\text { Units }\end{array}$ & $\begin{array}{c}\text { Charge } \\
\text { (\$/SFU/ } \\
\text { mo) }\end{array}$ \\
\hline Kitchener & $\$ 5821$ & $\$ 250$ & 178 & 120700 & $\$ 4.41$ & 259 & 81700 & $\$ 6.52$ & 259 & 81200 & $\$ 6.56$ \\
\hline Stratford & $\$ 7613$ & $\$ 50$ & 197 & 26500 & $\$ 25.37$ & 282 & 18700 & $\$ 35.95$ & 282 & 18700 & $\$ 35.95$ \\
\hline Waterloo & $\$ 3062$ & $\$ 150$ & 167 & 67500 & $\$ 4.17$ & 266 & 41500 & $\$ 6.79$ & 266 & 41300 & $\$ 6.82$ \\
\hline
\end{tabular}


The annual SWM program expenditures are shown for each city, comprising existing costs (the total program cost, shown in Table 23.2 above) plus the estimated cost to administer a stormwater rate on an annual basis. The latter component is a conceptual cost estimate of anticipated rate administration activities and includes an estimate of billing system costs plus the cost of city labor and expenses for engineering, legal, administrative, and financial staff.

The base charge is shown for the three stormwater rate billing unit methods (ERU, SFU and tiered SFU). For each method, Table 23.6 shows the base area, total number of billing units rounded to the nearest hundred, and the base charge to meet the respective funding requirements expressed in dollars per billing unit per month. The base charge calculation assumed that $5 \%$ of the rate revenue would go uncollected due to errors in billing, adjustments or credits, or delinquent accounts.

Table 23.6 highlights the typical observation when comparing the base charge between ERU and SFU methods. That is, the SFU charge is generally greater than the ERU charge since the SFU billing unit method assigns fractional billing units to multi-family residential properties, thus reducing the total number of stormwater billing units and therefore increasing the base charge to achieve the same revenue requirement.

During each of the studies, the development of rate structure scenarios and base charges followed an iterative process, and were modified to reflect the unique needs, policies and organizational structures of the respective cities. Rates were also modified as the result of feedback from the project steering and public advisory committees.

In each case, the actual study recommendations included scenarios that blended revenue from both the stormwater rate and the general property tax fund, with provisions for phasing in the rate over a period of years, rather than applying the full base charge at the beginning of the rate implementation. The results shown in Table 23.6 above do not reflect these recommended modifications, but are given solely for comparison purposes.

Further, it was noted earlier that long term financing scenarios were investigated in the Stratford study. Debt financing alternatives were investigated that reduced the overall SWM program cost to $\$ 3.3$ million/y (a $44 \%$ reduction), which resulted in a base charge of $<\$ 16 / \mathrm{SFU} /$ month, compared to \$36/SFU/month as shown in Table 23.6.

It has been estimated that the average stormwater rate charge in the U.S. is US\$4/billing unit/month, with an 11 th percentile to 90 th percentile range of $\$ 2 /$ month to $\$ 8 /$ month. 


\section{Impact Assessment}

For municipalities that currently fund their SWM program through property taxes, a stormwater rate would redistribute revenue from an assessed value basis to one based on runoff contribution as indicated by impervious area.

A comparison of the property tax levy versus the tiered SFU stormwater rate billing units is shown in Table 23.7. The table shows the distribution of revenue expressed as the allocation of charges among residential and non-residential properties. The property tax levy includes the municipal portion (i.e. regional government and education taxes collected by the city have not been included) and all values have been rounded to the nearest $\$ 10000$. The values for Kitchener and Waterloo are from 2007 and for Stratford are based on tax collection in 2006. Between two-thirds and three-quarters of the annual property tax revenue is attributable to residential properties in each of the three cities.

Table 23.7 Summary of tax versus rate revenue potential.

\begin{tabular}{lcrrrrr}
\hline & \multicolumn{3}{c}{ Property Tax Levy } & \multicolumn{3}{c}{ Stormwater Billing Units } \\
\cline { 2 - 7 } \multicolumn{1}{c}{ Municipality } & Total Levy & \multicolumn{1}{c}{ Res'1 } & Non-Res'1 & Tiered SFU & \multicolumn{1}{c}{ Res'l } & Non-Res'1 \\
\hline Kitchener & $\$ 85090000$ & $74.1 \%$ & $25.9 \%$ & 81200 & $65.3 \%$ & $34.7 \%$ \\
Stratford & $\$ 32790000$ & $69.3 \%$ & $30.7 \%$ & 18700 & $47.1 \%$ & $52.9 \%$ \\
Waterloo & $\$ 49000000$ & $73.8 \%$ & $26.2 \%$ & 41300 & $62.5 \%$ & $37.5 \%$ \\
\hline
\end{tabular}

The right portion of Table 23.7 shows the distribution of tiered SFU billing units, rounded to the nearest hundred. The results indicate that between one-half and two-thirds of the stormwater runoff contributed to the municipal SWM systems is attributable to residential properties.

The most dramatic difference between property tax and stormwater rate revenue for residential properties is evident in Stratford, where nearly $70 \%$ of the SWM program is currently funded by residential property tax although residential properties contribute $<50 \%$ of the stormwater runoff.

Figure 23.1 above illustrates the allocation by revenue source graphically for Stratford. The top portion shows the distribution of property tax revenue by the various property classifications. It is worth noting that some municipalities charge a core service fee or tax-like payment to certain tax-exempt properties. This payment in-lieu-of tax represents a small but significant component of the revenue used to support Stratford's SWM program.

The bottom portion of Figure 23.1 depicts the distribution of tiered SFU billing units by the same property classifications and illustrates how the allocation of revenue would be redistributed under a stormwater rate. With a tiered SFU stormwater rate, single-family detached homeowners as a whole would contribute $24 \%$ less towards the revenue needed to support the city's SWM program, compared to the current property tax revenue allocation. This differ- 
ence would be made up among the other property classifications, resulting in an increased contribution of $2 \%$ for multi-family residential, $14 \%$ for nonresidential, and $8 \%$ for non-residential tax-exempt properties.
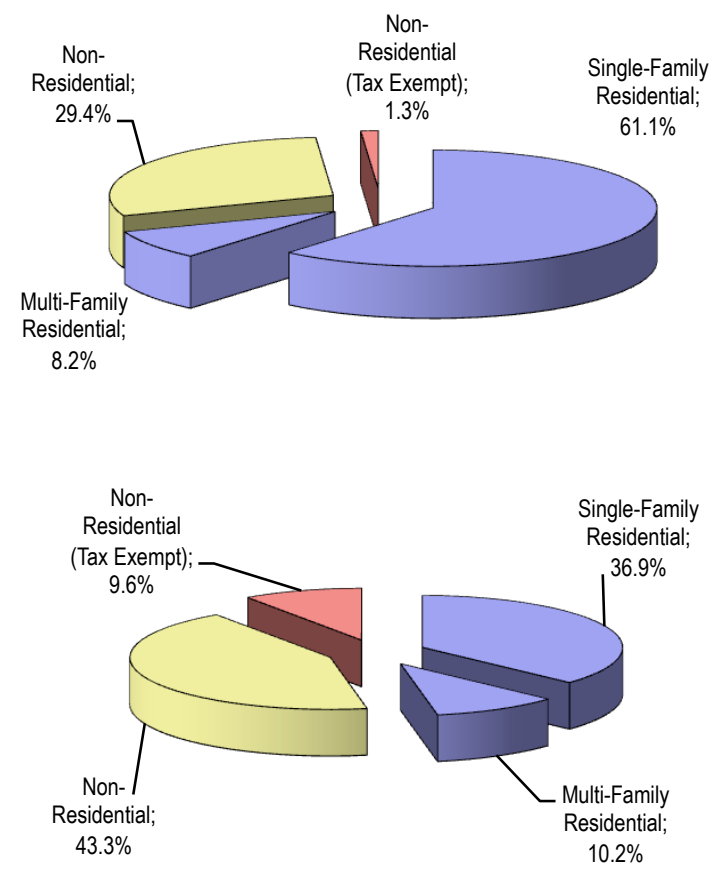

Figure 23.1 Distribution of Stratford SWM program revenue-property tax (top) versus tiered SFU rate revenue (bottom).

To investigate the impacts to property owners in more detail, a comparison of the SWM program revenue allocation was made between the current property tax funding and a stormwater rate based on the tiered SFU billing unit method. Tables 23.8, 23.9 and 23.10 show the results of these comparisons for the cities of Kitchener, Stratford and Waterloo.

For each general parcel category in Tables 23.8, 23.9 and 23.10 the portion of the annual property tax that is currently used to support the city's SWM program is shown followed by the number of tiered SFU billing units and the annual stormwater rate revenue that would be generated. The next column shows the annual revenue difference (stormwater rate versus property tax) among each property class. The total difference across all property types is $\$ 250000$ for Kitchener \$50 000 for Stratford and \$150 000 for Waterloo (approximately due to rounding of numbers) which corresponds to the estimated 
rate administration cost that was shown in Table 23.6 above. The final column shows the difference on a monthly basis across all parcels in each property class representing the difference in the average base charge to each property owner. A negative number indicates a reduced monthly charge compared to current tax funding. The average charge across all property types is shown in the bottom right corner of the table. This value is approximately $\$ 0.40 /$ property owner/month and represents the increased cost of the stormwater rate administration.

Table 23.8 Kitchener annual tax versus rate comparison (tiered SFU).

\begin{tabular}{|c|c|c|c|c|c|c|c|c|}
\hline \multirow{2}{*}{$\begin{array}{c}\text { Parcel } \\
\text { Type }\end{array}$} & \multicolumn{2}{|c|}{$\begin{array}{l}\text { Property Tax } \\
\text { Revenue }\end{array}$} & \multirow{2}{*}{$\begin{array}{c}\text { Tiered } \\
\text { SFU }\end{array}$} & \multicolumn{2}{|c|}{$\begin{array}{c}\text { Tiered SFU } \\
\text { Revenue }\end{array}$} & \multicolumn{2}{|c|}{ Rate vs. Tax } & \multirow{2}{*}{$\begin{array}{c}\text { Average } \\
\text { (parcel/ } \\
\text { mo) }\end{array}$} \\
\hline & Amount & $\%$ & & Amount & $\%$ & Annual \$ & $\%$ & \\
\hline $\begin{array}{l}\text { Single Family } \\
\text { Res'l }\end{array}$ & $\$ 3527000$ & 60.6 & 41400 & $\$ 3096000$ & 51.0 & $-\$ 431000$ & -12.2 & $-\$ 0.9$ \\
\hline $\begin{array}{l}\text { Multi-Family } \\
\text { Res'l }\end{array}$ & $\$ 785000$ & 13.5 & 11600 & $\$ 867000$ & 14.3 & $\$ 82000$ & 10.4 & $\$ 0.6$ \\
\hline Non-Residential & $\$ 1324000$ & 22.7 & 20700 & $\$ 1548000$ & 25.5 & $\$ 224000$ & 16.9 & $\$ 6.7$ \\
\hline $\begin{array}{l}\text { Non-Res'l (Tax } \\
\text { Exempt) }\end{array}$ & $\$ 185000$ & 3.2 & 7500 & $\$ 561000$ & 9.2 & $\$ 376000$ & 203.2 & $\$ 33.9$ \\
\hline Total & $\$ 5821000$ & 100.0 & 81200 & $\$ 6072000$ & 100.0 & $\$ 251000$ & 4.3 & $\$ 0.37$ \\
\hline
\end{tabular}

Table 23.9 Stratford annual tax versus rate comparison (tiered SFU).

\begin{tabular}{|c|c|c|c|c|c|c|c|c|}
\hline \multirow{2}{*}{$\begin{array}{l}\text { Parcel } \\
\text { Type }\end{array}$} & \multicolumn{2}{|c|}{$\begin{array}{c}\text { Property Tax } \\
\text { Revenue }\end{array}$} & \multirow{2}{*}{$\begin{array}{c}\text { Tiered } \\
\text { SFU } \\
\text { Bill Units }\end{array}$} & \multicolumn{2}{|c|}{$\begin{array}{l}\text { Tiered SFU } \\
\text { Revenue }\end{array}$} & \multicolumn{2}{|c|}{ Rate vs. Tax } & \multirow{2}{*}{$\begin{array}{c}\text { Average } \\
\text { (parcel/ } \\
\text { mo) }\end{array}$} \\
\hline & Amount & $\%$ & & Amount & $\%$ & Annual \$ & $\%$ & \\
\hline $\begin{array}{l}\text { Single Family } \\
\text { Res'l }\end{array}$ & $\$ 4653000$ & 61.1 & 6900 & $\$ 2828000$ & 36.9 & $\begin{array}{r}\$ 1825 \\
000\end{array}$ & -39.2 & $-\$ 22.1$ \\
\hline $\begin{array}{l}\text { Multi-Family } \\
\text { Res'l }\end{array}$ & $\$ 622000$ & 8.2 & 1900 & $\$ 779000$ & 10.2 & $\$ 157000$ & 25.2 & $\$ 5.6$ \\
\hline Non-Residential & $\$ 2242000$ & 29.4 & 8100 & $\$ 3320000$ & 43.3 & $\begin{array}{r}\$ 1078 \\
000\end{array}$ & 48.1 & $\$ 132.9$ \\
\hline $\begin{array}{l}\text { Non-Res'l (Tax } \\
\text { Exempt) }\end{array}$ & $\$ 96000$ & 1.3 & 1800 & $\$ 738000$ & 9.6 & $\$ 642000$ & 668.8 & $\$ 219.3$ \\
\hline Total & $\$ 7613000$ & 100.0 & 18700 & $\$ 7665000$ & 100.0 & $\$ 52000$ & 0.7 & $\$ 0.43$ \\
\hline
\end{tabular}

Table 23.10 Waterloo annual tax versus rate comparison (tiered SFU).

\begin{tabular}{|c|c|c|c|c|c|c|c|c|}
\hline \multirow{2}{*}{$\begin{array}{l}\text { Parcel } \\
\text { Type }\end{array}$} & \multicolumn{2}{|c|}{$\begin{array}{l}\text { Property Tax } \\
\text { Revenue }\end{array}$} & \multirow{2}{*}{$\begin{array}{c}\text { Tiered } \\
\text { SFU } \\
\text { Bill Units }\end{array}$} & \multicolumn{2}{|c|}{$\begin{array}{c}\text { Tiered SFU } \\
\text { Revenue }\end{array}$} & \multicolumn{2}{|c|}{ Rate vs. Tax } & \multirow{2}{*}{$\begin{array}{c}\text { Average } \\
\text { (parcel/ } \\
\text { mo) }\end{array}$} \\
\hline & Amount & $\%$ & & Amount & $\%$ & Annual \$ & $\%$ & \\
\hline $\begin{array}{l}\text { Single Family } \\
\text { Res'l }\end{array}$ & $\$ 1983000$ & 64.8 & 19800 & $\$ 1539000$ & 47.9 & $\$ 444000$ & -22.4 & $-\$ 1.8$ \\
\hline $\begin{array}{l}\text { Multi-Family } \\
\text { Res'l }\end{array}$ & $\$ 277000$ & 9.1 & 6000 & $\$ 466000$ & 14.5 & $\$ 189000$ & 68.2 & $\$ 1.6$ \\
\hline $\begin{array}{l}\text { Non- } \\
\text { Residential }\end{array}$ & $\$ 703000$ & 22.9 & 11700 & $\$ 910000$ & 28.3 & $\$ 207000$ & 29.4 & $\$ 10.3$ \\
\hline $\begin{array}{l}\text { Non-Res'l } \\
\text { (Tax Exempt) }\end{array}$ & $\$ 99000$ & 3.2 & 3800 & $\$ 295000$ & 9.2 & $\$ 196000$ & 198.0 & $\$ 29.3$ \\
\hline Total & $\$ 3062000$ & 100.0 & 41300 & $\$ 3210000$ & 100.0 & $\$ 148000$ & 4.8 & $\$ 0.39$ \\
\hline
\end{tabular}


These tables illustrate the revenue redistribution and resulting charge allocation whereby the average single family detached homeowner would be subjected to a reduced charge of approximately $\$ 0.90 /$ month, $\$ 22.10 /$ month and $\$ 1.80 /$ month respectively in Kitchener, Stratford and Waterloo. The average property owner in other categories would see a resulting increase in their charge to support the city's SWM program a reflection of the redistribution impact highlighted by Figure 23.1. As expected, tax exempt parcels would be impacted the most as a stormwater rate would represent a new expense to property owners.

In each of these studies the impact to individual property owners was further assessed by selecting a variety of sample properties in each city, and comparing the various recommended rate structure options to current tax funding on a monthly basis. Results varied widely from the average impact values described above. As expected, the greatest disparity between tax-based charges and rate charges (the properties that would see the greatest reduction in their stormwater charge under a rate structure) were indicated for those properties with the highest ratio of property value assessment to impervious area. As an example, for properties with the same assessed value, a high-rise office tower with underground parking would generally pay a lower monthly stormwater rate charge than a low-rise commercial or industrial building with surface parking and a large impervious footprint.

\subsection{Discussion}

This section summarizes the experience gained in SWM financing studies throughout North America. The discussion focuses on the practical issues and concerns that need to be addressed by municipalities that are considering implementing a stormwater rate. A common set of critical success factors is listed followed by a discussion of the key stormwater rate issues and challenges.

\subsubsection{Critical Success Factors}

Despite wide variations in the hydrologic and socio-political climates across North America, as well as differences in the needs resources and organizational structure of jurisdictions, a general set of critical success factors for municipal SWM financing has been developed as follows:

1. Recognize that one size does not fit all: Each community's SWM program has unique needs - preferred solutions, organizational structures, staff experience and knowledge, equipment, 
and resources; there is no single financing mechanism that can address the needs of all municipalities;

2. Collaborate with stakeholders and promote communication: Stakeholders need to be chosen carefully and must be representative of the citizenry and property owners who will be paying for the SWM program; further, the stakeholder-meeting facilitator needs to ensure that facts have been presented and understood, to inspire collaborative dialog, and to be impartial in the decision making process yet skilled at marshalling divergent opinions towards group consensus;

3. Define the champion and home of the program: The champion(s) of the funding program could be a respected community leader, activist, councillor or staff member; the home of the program can refer to the local government and the department in which the program resides (e.g. Engineering, Finance, or Public Works);

4. Clearly define the health, safety and welfare benefits: The guiding principles behind the municipal SWM program should be, first and foremost, the health, safety and welfare of residents and business owners; adhering to good SWM practices and principles will also benefit the environment and have a positive impact on aquatic habitats; clearly documenting and defining a municipality's SWM issues, problems and needs along with the corresponding solutions, services and expenditures, is a necessary step in identifying the optimal funding mechanism;

5. Clearly define the cost of each program element: The level of service provided by the municipal SWM program directly affects the overall program cost; public trust and confidence can only be gained through a clear and transparent accounting of service activities, assets and expenditures;

6. Allocate level of service by geography: There are clear spatial differences between SWM facilities and O\&M services in an urban setting and a rural setting (e.g. curb or gutter with storm sewers versus roadside ditching); even within a rural setting, for example, there can be different service costs for operations and maintenance activities and capital projects; depending on topography and vegetative cover; these differences should be considered in the rate-setting process;

7. Pragmatically address inter-jurisdictional issues within watersheds: Political boundaries often present roadblocks to 
managing SWM and other water resources programs; joint initiatives can realize great cost efficiencies in SWM services and capital projects;

8. Keep abreast of new legislation and initiatives: It is important for municipal staff to be attentive to upcoming SWM regulations, funding opportunities, and new technologies in order to bolster long term program planning and identify future cost efficiencies in service delivery;

9. Provide clear documentation for customer fees: Regardless of the funding mechanism that is ultimately selected, customer relations will be improved when an effort is made to clearly explain the stormwater charges; and

10. Establish policies to address private property issues: With an increasing focus on SWM source controls, it is becoming increasingly important to establish municipal policies to assist in dealing with these private property issues.

\subsubsection{Public Consultation Program}

In each of the Ontario studies presented earlier, a unique public consultation program was developed to assist the project team with stormwater level of service, affordability and funding decisions as well as to gauge and develop public understanding and support for the study recommendations. A key feature of these public consultation programs included the development and facilitation of a Stormwater Advisory Committee (SWAC) whose members represented different segments of the community and brought to the discussion the interests and concerns of each group. The typical SWAC process included facilitating regular monthly meetings and generally a total of 6-8 meetings were held with each lasting approximately 90 minutes.

Given the typically low profile and level of understanding of the municipal SWM program by the general public, the formation of an advisory committee is a critical undertaking in a stormwater rate. A successful SWAC process will address the more contentious issues of key stakeholder groups at an early stage.

\subsubsection{Rate Implementation and Administration Costs}

Common misconceptions of a stormwater rate include significant implementation costs and the need to reorganize the administration structure. It is therefore 
important to address these misconceptions at an early stage by presenting factual accounts of all anticipated costs.

The biggest rate implementation cost items are the rate study, billing and database management (both start-up and ongoing service), and time for staff to examine credit applications and review site development plans for impervious area calculations. Additional costs include staff labor, expenses, and indirect overhead for engineering, legal, and financial functions during the rate study and ongoing service.

In many U.S. stormwater rate implementations, municipalities already had existing utility billing systems and customer service agents to help minimize billing costs. Further new staff hiring is typically limited to a half or one fulltime equivalent position and it is common for the roles and responsibilities of a few existing staff members to be broadened. Although a stormwater rate does not generally result in organizational restructuring it does force a change in financial reporting methods towards better cost accounting. Itemizing specific SWM labor and equipment expenditures is a good business practice and not necessarily a challenge.

\subsubsection{Level of Service Enhancements}

By introducing a new funding method concurrently with SWM program enhancements (i.e. higher level of service that increases revenue requirements) there often is a concern that the new stormwater rate may be perceived as the reason for the increased cost to ratepayers. It is therefore critically important to clearly distinguish level of service enhancement issues separately. That is, studies and investigations need to clearly separate the cost for new improvements versus costs for existing operations.

In many cases, stormwater rates will be handled differently depending on the level of program planning that has been done. Based on experience with stormwater financing studies throughout North America the following strategy is suggested:

- $\quad$ For municipalities that have not clearly identified their future program costs (i.e. minimal master planning activities have been completed), it is best to use the current level of service expenditures as the basis for the initial stormwater rate; that is, the rate should initially support the current level of service, and then slowly increase over subsequent years to meet future level of service requirements, as the master planning studies are com- 
pleted and the capital improvement program and operational requirements become clearer;

- If some capital and operational planning has been done, then modest level of service cost increases can be included in the initial implementation of a stormwater rate, or the ramp-up period to achieving the full future level of service expenditures could be reduced; and

- Municipalities that have completed significant capital and operational planning studies, especially those that have gone through a public and political process (as was the case in Stratford), can use the future level of service expenditures to set the initial stormwater rate.

\subsubsection{Property Owner Incentives}

A stormwater rate provides incentives for property owners to provide on-site controls that reduce their individual contributions of stormwater runoff and pollutant loading to the municipal SWM system. This is achieved through the adoption of a credit policy, which typically rewards property owners with a reduced charge if they do something to improve the quantity and quality of runoff discharged to the municipal SWM system (i.e. they reduce the municipality's fiscal responsibilities or otherwise provide direct savings to the municipal SWM program).

Credits, if awarded, would reduce a property owner's base charge if their on-site facilities have been properly designed and constructed, and are maintained on a regular basis. Credits could also apply if the property is located in an unusual place, such that runoff is not directed to the municipal SWM system.

One of the biggest implementation challenges of a rate study is in achieving consensus among ratepayers on the credit policy details. Credit and incentive programs should first target property owners with large impervious footprints (such as industries, shopping malls, business parks). For the numerous, though smaller, impervious footprints of residential property owners, experience has shown that a bigger overall impact can be achieved through public education on good SWM housekeeping practices rather than through a credit program for individual homeowners. 


\subsection{Conclusions}

A growing trend among municipalities in North America is to anticipate significant increases in future SWM program costs due to a variety of factors including:

- Level of service enhancements to address needed operations and maintenance activities;

- Accelerated capital improvement projects;

- The retrofit of existing facilities or construction of new facilities to address new water quality regulations;

- The replacement or rehabilitation of aging infrastructure; and

- Increased maintenance activities as new development infrastructure is assumed.

As a result of these cost increases, municipalities will need a greater emphasis on sound asset management and long term financial planning. This would include guidance for municipalities during all anticipated growth and development situations.

This chapter was intended to highlight issues and approaches in developing a stormwater rate as a sustainable financing option for Canadian municipalities. Recent case studies in Ontario were summarized as a means of documenting a typical stormwater rate analysis.

A stormwater rate offers unique advantages over other municipal SWM program financing options and provides more budgeting flexibility than property tax or development-related funding. A stormwater rate charges property owners based on their relative contribution of stormwater runoff volume and pollutant loading whereas property tax funding is only based on assessed property value and development charges are based on total number of dwelling units or land area.

The implementation of a stormwater rate represents more than a mere reallocation of municipal SWM program costs compared to current revenue sources. It also supports the overall goals and objectives of many municipalities on three key fronts. That is, the implementation of a stormwater rate:

- Achieves the principles of fairness and equity by allocating charges based on runoff contribution;

- $\quad$ Provides a dedicated, sustainable, and flexible mechanism to support the current and future needs of the SWM program especially for municipalities that have identified significant increases in revenue requirements; and 
- Offers financial incentives for property owners to provide onsite controls to reduce stormwater and pollutant loads to the municipal SWM system; not only is there an inherent developer incentive for installing stormwater source controls (since they reduce land requirements for end-of-pipe facilities and therefore can reduce overall SWM construction costs), but property owners with source controls would be eligible for stormwater rate credits.

\section{Acknowledgments}

The authors would like to thank the following people for their enthusiasm and efforts in conducting the stormwater rate studies described in this chapter:

- City of Kitchener: Grant Murphy, Dan Chapman and Kevin Mick;

- City of Stratford: Ron Shaw, George Bowa, Joe Salter, Ray Nothdurft and Phil Buxton;

- City of Waterloo: Sunda Siva, Cassandra Pacey, Denise McGoldrick and Filipa Reynolds;

- CDM: Don Stone; and

- AECOM: Nicole Weber.

\section{References}

Camp Dresser \& McKee Inc. (2005). Recommendations for Stormwater Utility Implementation in New Jersey Final Report September 2005.

Florida Stormwater Association (2007). Stormwater Utilities Survey.

Gregory, M., J. Aldrich, A. Holtshouse and K. Dreyfuss-Wells. 2006.

"Evaluation of Imperviousness Impacts in Large, Developing Watersheds." Journal of Water Management Modeling R225-06. doi: 10.14796/JWMM.R225-06.

Lee Joong Gwang and James P. Heaney (2003). Estimation of Urban Imperviousness and its Impacts on Storm Water Systems. Journal of Water Resources Planning and Management Vol. 129 (5) pages 419-426.

McClelland Scott Steven Sedgwick and Philip Chernin (2003). Billing Structure and Data Collection Methods. In: Establishing a Stormwater Utility in Florida Florida Stormwater Association chapter 5.

Schueler Thomas R. (2003). Impacts of Impervious Cover on Aquatic Systems Center for Watershed Protection Ellicott City MD 
Stocker J. (1998). Methods for Measuring and Estimating Impervious Surface Coverage. Technical Paper No. 3; University of Connecticut Nonpoint Education for Municipal Officials.

Totten Sims Hubicki Associates and Camp Dresser \& McKee Inc. (2007). City of Stratford Stormwater Rate Study and Implementation Plan Final Report April 2007.

Totten Sims Hubicki Associates and Camp Dresser \& McKee Inc. (2008a). KitchenerWaterloo Stormwater Management Program and Funding Review: Stormwater Funding Analysis Draft Final Report October 2008.

Totten Sims Hubicki Associates and Camp Dresser \& McKee Inc. (2008b). Credit River Water Management Strategy Update-Municipal Stormwater Financing Study Internal Working Document-Final October 2008.

U.S. Environmental Protection Agency (1997). Urbanization and Streams: Studies of Hydrologic Impacts Office of Water Publication 841-R-97-009 Washington DC. 